\begin{tabular}{r}
\hline \hline 811.163.41'374 \\
811.163 .41 '354 \\
811.163 .41 373.611 \\
https://doi.org/10.18485/msc.2018.47.1.ch36
\end{tabular}

Горан Н. ЗЕЉИЋ*

Оригинални научни рад

Универзитет у Београду

Примљен: 25. 10. 2017.

Учитељски факултет

Прихваћен: 27. 12. 2017.

\title{
ПРЕФИКСОИДИ И СРОДНИ СТРАНИ ФОРМАНТИ У ПРАВОПИСНИМ РЕЧНИЦИМА СРПСКОГ ЈЕЗИКА
}

\begin{abstract}
У раду ће бити анализирани префиксоиди и сродни форманти страног порекла (најчешће грчког и латинског) који су увршћени у правописне речнике српског језика почев од Белићевог правописа из 1923. године, преко Матичиних издања од 1960. до данас и Дешићевог правописа 2015. године, до Симићевог нормативног приручника из 2016. године. Циљ рада је да се испита заступљеност речи са префиксоидима и страним формантима у правописним речницима српског језика и установи принцип њихове ортографске стандардизације.
\end{abstract}

Кључне речи: правопис, правописни речник, префиксоид, сложеница, полусложеница.

\section{1. Увод}

1. На основу једне од класификација речника, правописни речници били би сврстани у специјалне речнике. Правописни речник је онај практични део правописног приручника у којем су дате речи „с циљем да се корисници упознају како их ваља писати без претензија на карактеризацију њихове лексичке и граматичке нормативности” (Симић и др. 1993: 157). Први правопис са дводелном структуром која је подразумевала правописна правила и речник био је Белићев правопис српскохрватског језика из 1923. године, који је издањем из $1952^{1}$. добио прави облик, обим и намену. Као посебно дело, правописни речник издвојио је М. Шипка (2010).

2. Имајући у виду одређене помаке у настави правописа који подразумевају увођење правописних приручника у наставу и упутства како их треба

*goran.zeljic@uf.bg.ac.rs

${ }^{1}$ Припремљен 1950, а објављен 1952. године. 
користити (Ломпар 2012: 114), наш циљ управо је да проверимо могу ли се на примеру префиксоида и сродних страних форманата у правописним речницима извести одређени закључци у вези са њиховим нормирањем и да ли на основу њихове презентације у тим речницима корисници правописних приручника могу уочити извесне правилности. У раду ће бити анализирани префиксоиди и форманти страног порекла (најчешће грчког и латинског) који су увршћени у правописне речнике српског језика почев од Белићевог правописа из 1923. године, преко Матичиних издања почев од 1960. године и Дешићевог правописа 2015. године, до Симићевог нормативног приручника из 2016. године.

3. У нормативним приручницима писање префиксоида и страних форманата део је теме посвећене састављеном и растављеном писању речи. Управо ова тема једна је од најтежих правописних тема, а дилеме у вези с њом (и не само њом) најчешће се решавају пре свега коришћењем правописних речника у оквиру правописних приручника. На основу тога, за потребе анализе издвојено је више префиксоида и сродних страних форманата (авио-, аеро-, анти-, архи-, аудио-, ауто-, видео-, екс-, екстра-, етно-, инфра-, квази-, контра-, макро-, макси-, мега-, микро-, мини-, пост-, псеудо-, суб-, супер-, транс-, ултра-, фото-, хипер-) у примерима датим у правописним речницима. Уз то, на примерима из новинских текстова биће показано и која огрешења су фреквентна у пракси, настала често под утицајем графије у енглеском језику (нпр. у употреби префиксоида пост- и екс-).

\section{2. Терминологија}

1. Питање назива за творбене морфеме страног порекла овде је решено употребом назива који је коришћен у последњем Матичином правопису (у оба издања - 1993. и 2010). Дилема да ли су то страни префикси, префиксоиди или везане морфеме страног порекла овде није била у првом плану и као задатак ставља се пред морфологе. Овим питањем бавили су се многи и оно је разматрано и у граматичкој и у правописној литератури. Већина радова бави се и начином писања ових форманата, али је терминологија неуједначена ${ }^{2}$. Може се рећи да се поред назива префиксоид (у радовима: Клајн 1978; Поповић 1994; Радовић Тешић 2009; у граматикама Станојчић/Поповић 2008; Пипер/Клајн 2013), појављују још и предметак (Рогић 1961/62; Пешикан 199433), терминоелеменат (Михаиловић 1985 за видео-) итд. Иван Клајн прави разлику између префикса, који „имају уопштено, више релационо него лексичко значење”, и префиксоида ${ }^{4}$, који „задржавају значење целих

${ }^{2} \mathrm{У}$ хрватској литератури префиксоиде и суфиксоиде називају још и адјективни морфеми, аглутинативни елементи, аналитички адјективи, квазипрефикси, лексикоморфеми, полипрефикси, препозитивни блокови итд. (Хорват/Штебих Голуб 2010: 1).

${ }^{3}$ Пешикан користи и назив префикс (1994: 270)

4 „Понекад је врло тешко одредити да ли је нека јединица префикс или префиксоид, суфикс или суфиксоид” (Тафра/Кошутар 2009: 99). 
речи" (Клајн 1978: 188; 2002: 144), на шта указује и Марко Поповић (1994: 280). За Мирослава Николића први део сложеница/полусложеница типа $а у$ томеханичар јесу префиксоиди и он их доводи у везу са сложеницама типа Беобанка и сл. (Николић 1995-1996: 85). Владан Јовановић на материјалу Речника САНУ те творбене елементе (као што су аеро-, анти, квази- и сл.) такође назива префиксоидима и истиче њихово лексичко а не творбено значење „какво имају суфикси и префикси” (Јовановић 2008: 47). Б. Ћорић се такође бави овим формантима, па их назива препозитивне индеклинабилне компоненте страног порекла (2008: 121).

2. Када су у питању анализирани правописи, преовлађује назив префиксоид.

\section{3. Анализа}

1. Прво ћемо представити заступљеност префиксоида у анализираним правописним речницима почев од првог Матичиног приручника јер у Белићевом правопису из 1923. налазимо само архи- (Белић 1923: 158), а у издању из 1952. год. ауто- (у значењу „само”, Белић 1952: 132). Одабир префиксоида вршили смо по П2010 јер је то актуелан нормативни приручник.

Табела 1: Заступљеност префиксоида и сродних страних форманата

\begin{tabular}{|c|c|c|c|c|c|}
\hline \multirow{2}{*}{$\begin{array}{l}\text { Префиксоиди и } \\
\text { сродни страни } \\
\text { форманти П2010 }\end{array}$} & \multicolumn{5}{|c|}{ Правописни приручници } \\
\hline & МП60 & МП93 & $\begin{array}{c}\text { Дешић } \\
2015\end{array}$ & $\begin{array}{l}\text { Симић и } \\
\text { др. } 1993\end{array}$ & $\begin{array}{c}\text { Симић } \\
2016\end{array}$ \\
\hline авио- & + & + & + & + & + \\
\hline aepo- & + & + & + & + & + \\
\hline анти-* & + & + & + & + & + \\
\hline архи-* & + & + & + & + & - \\
\hline аудио- & - & - & + & - & - \\
\hline ауто- & + & + & + & + & + \\
\hline видео- & - & + & + & + & - \\
\hline екс-* & + & + & + & + & + \\
\hline екстра-* & + & + & + & + & + \\
\hline етно- & + & + & + & + & - \\
\hline инфра-* & - & + & + & - & + \\
\hline квази-* & - & - & + & - & - \\
\hline
\end{tabular}




\begin{tabular}{|l|c|c|c|c|c|}
\hline контра-* & + & + & + & + & + \\
\hline макро- & - & + & + & + & + \\
\hline макси- & - & - & - & + & + \\
\hline мега- & + & + & + & + & + \\
\hline микро- & + & + & + & + & + \\
\hline мини-* & + & + & + & + & + \\
\hline пост-* & + & + & + & + & + \\
\hline псеудо-* & + & + & + & + & + \\
\hline суб-* & + & + & + & + & + \\
\hline супер-* & + & + & + & + & + \\
\hline транс-* & + & + & + & + & + \\
\hline ултра-* & + & + & + & + \\
\hline фото- & + & + & + & + \\
\hline хипер-* & + & + & + & + \\
\hline
\end{tabular}

* Форманти са овом ознаком сврстани су у литератури у префиксе (нпр. Бабић $2002^{5}$; Клајн 2002; Ломпар 2015).

2. У представљању префиксоида и сродних страних форманата аутори правописних речника имају два приступа. Матичини правописи, већ од приручника из 1960. године, ове форманте издвајају као посебне одреднице (нпр. авио-: авио-гума, авио-гориво, авио-карта итд., П2010: 254). Други начин представљања налазимо нпр. код Симића (2016). У овом приручнику речи с овим формантима су посебне одреднице са квалификаторима попут акц. преф.; факулт. слож.; удв. (нпр. супер-мёдји, акц. преф.; суперрѐвизија (или супер-рѐвизија и супер рѐвизија) факулт. слож. 222 (исп. 218); удв. 219; Симић 2016: 235).

3. У табели која следи дат је преглед решења у вези са писањем префиксоида и сродних страних форманата.

${ }^{5}$ Тако су нпр. везане основе агро-, хидро-, макро-, микро-, јер значе 'земљо-', 'водо- ', 'велико', мал(ен)о', а префикси анти-, архи-, интер-, супер-, ултра-, јер значе проту, изнад, над-, међу-, нај-, преко (Бабић 2002: 37). „Префиксоиди се не могу јављати самостално, а најчешће имају два слога (макро-, гео-, етно-, микро-, фото-) и завршавају се на o" (Ломпар 2015: 15). „Може се стога закључити да је финално $о$ једно од типичних обележја префиксоида. То још не значи да ћемо облицима мега-, екстра-, теле-, мулти-, поли-, уни-, квази-, мини-, макси-, аку- (у акупнуктура и акупресура) унапред порећи статус префиксоида само због завршног вокала" (Клајн 2002: 147).

${ }^{6}$ Наглашене масним словима (болдом). 
Табела 2: Преглед решења у анализираним правописним приручнищима

\begin{tabular}{|c|c|c|c|c|c|c|}
\hline \multirow{3}{*}{$\begin{array}{l}\text { Префиксоиди и } \\
\text { сродни страни } \\
\text { форманти }\end{array}$} & \multicolumn{6}{|c|}{ Правописни приручници } \\
\hline & \multicolumn{6}{|c|}{$\begin{array}{c}\text { С - сложеница; П - полусложеница; ДР - две речи; } \\
\text { ДУБ - дублет; ТРИП - триплет }\end{array}$} \\
\hline & МП60 & МП93 & П2010 & $\begin{array}{l}\text { Дешић } \\
2015\end{array}$ & $\begin{array}{l}\text { Симић и } \\
\text { др. } 1993\end{array}$ & $\begin{array}{c}\text { Симић } \\
2016\end{array}$ \\
\hline авио- & $\Pi$ & $\Pi / \mathrm{C}$ & $\Pi$ & $\Pi / \mathrm{C}$ & $\Pi$ & $\Pi$ \\
\hline aepo- & $\mathrm{C}$ & $\mathrm{C} / \Pi$ & $\mathrm{C} / \Pi$ & $\Pi / \mathrm{C}$ & $\Pi / \mathrm{C}$ & $\Pi / \mathrm{C}$ \\
\hline анти-* & $\mathrm{C}$ & $\mathrm{C}$ & $\mathrm{C}$ & $\mathrm{C}$ & $\mathrm{C}$ & $\mathrm{C} / \Pi$ \\
\hline архи-* & $\mathrm{C}$ & $\mathrm{C}$ & $\mathrm{C}$ & $\mathrm{C}$ & $\mathrm{C}$ & l \\
\hline аудио- & l & l & $\Pi$ & $\mathrm{C} / \Pi$ & l & l \\
\hline ауто- & $\mathrm{C} / \Pi$ & $\mathrm{C} / \Pi$ & $\Pi / \mathrm{C}$ & $\Pi / \mathrm{C}$ & $\Pi$ & П/C \\
\hline видео- & l & $\begin{array}{l}\mathrm{C} / \Pi / \\
\text { ДР }\end{array}$ & $\Pi / \mathrm{C}$ & $\Pi / \mathrm{C}$ & $\Pi / \mathrm{C}$ & l \\
\hline екс-* & $\mathrm{C}$ & $\mathrm{C}$ & $\mathrm{C}$ & $\mathrm{C}$ & $\Pi$ & $\Pi$ \\
\hline екстра-* & $\mathrm{C}$ & С/ДР & С/ДР & $\mathrm{C}$ & С/ДР & $\Pi$ \\
\hline етно- & $\mathrm{C}$ & $\mathrm{C}$ & $\mathrm{C} / \Pi$ & $\mathrm{C}$ & $\mathrm{C}$ & l \\
\hline инфра-* & / & $\mathrm{C}$ & $\mathrm{C}$ & $\mathrm{C}$ & / & $\Pi$ \\
\hline квази-* & I & I & $\mathrm{C}$ & $\mathrm{C}$ & I & I \\
\hline контра-* & $\mathrm{C}$ & $\mathrm{C}$ & $\mathrm{C}$ & $\mathrm{C}$ & $\Pi$ & $\Pi$ \\
\hline макро- & / & $\mathrm{C}$ & $\mathrm{C}$ & $\mathrm{C}$ & $\mathrm{C} / \Pi$ & $\mathrm{C} / \Pi$ \\
\hline макси- & / & / & $\Pi$ & / & / & / \\
\hline мега- & $\mathrm{C}$ & $\mathrm{C}$ & $\mathrm{C}$ & $\mathrm{C}$ & $\mathrm{C}$ & / \\
\hline микро- & $\mathrm{C}$ & $\mathrm{C}$ & $\mathrm{C}$ & $\mathrm{C}$ & $\Pi / \mathrm{C}$ & $\begin{array}{l}\text { С/П/ } \\
\text { ДУБ }\end{array}$ \\
\hline мини-* & $\mathrm{C}$ & П/ДР & $\mathrm{C} / \Pi$ & $\mathrm{C} / \Pi$ & П/ДУБ & $\Pi$ \\
\hline пост-* & $\mathrm{C}$ & $\mathrm{C}$ & $\mathrm{C}$ & $\mathrm{C}$ & ДУБ/С/П & ДУБ \\
\hline псеудо-* & $\mathrm{C}$ & $\mathrm{C}$ & $\mathrm{C}$ & $\mathrm{C}$ & $\Pi$ & / \\
\hline суб-* & $\mathrm{C}$ & $\mathrm{C}$ & $\mathrm{C}$ & $\mathrm{C}$ & с/ДУБ & ДУБ \\
\hline супер-* & $\mathrm{C}$ & $\mathrm{C}$ & С/ДР & $\mathrm{C}$ & С/ДУБ & $\begin{array}{c}\mathrm{C} / \\
\text { ТРИП }\end{array}$ \\
\hline транс-* & $\mathrm{C}$ & $\mathrm{C}$ & $\mathrm{C}$ & $\mathrm{C}$ & $\mathrm{C}$ & $\mathrm{C}$ \\
\hline
\end{tabular}




\begin{tabular}{|l|c|c|c|c|c|c|}
\hline ултра-* & $\mathrm{C}$ & $\mathrm{C}$ & $\mathrm{C}$ & $\mathrm{C}$ & $\Pi$ & $\Pi$ \\
\hline фото- & $\mathrm{C} / \Pi$ & $\mathrm{C} / \Pi$ & $\mathrm{C} / \Pi$ & $\mathrm{C} / \Pi$ & $\Pi / \mathrm{C}$ & $\Pi / \mathrm{C}$ \\
\hline хипер-* & $\mathrm{C}$ & $\mathrm{C}$ & $\mathrm{C}$ & $\mathrm{C}$ & $\mathrm{C}$ & ДУБ \\
\hline
\end{tabular}

4. Од одабраних префиксоида, само је решење предвиђено за писање префиксоида транс- уједначено у свим консултованим приручницима, и то као први део сложеница. Као посебне речи са прилошким или придевским значењем, употребљавају се пре свега префиксоиди екстра- (у значењу „сјајно”) и супер- (у значењу „одлично, сјајно”) - дакле са синонимним значењем у жаргонској употреби.

5. Видимо да је највише сложеница, што се уклапа у Бабићеву констатацију: „творенице с основама као што су аеро-, ауто-, фото-, кино-, радио- и сл. често су се сматрале полусложеницама и тако се писале, али да има много разлога да се сматрају и чистим сложеницама" (Бабић 2002: 47) 7 .

6. Од понуђених критеријума, у Матичиним правописима истиче се разлика у писању префиксоида ауто- и фото- у односу на скраћене појмове аутомобил(ски) и фотографски - када је реч с тим појмом полусложеница (нпр. ауто-пут). За Симића (2016) критеријум је акценат - те ако је префиксоид акцентован, биће први део полусложенице (нпр. àymo-nŷm насупрот aутостра́da). Од три актуелна нормативна приручника - Матичином, Дешићевом и Симићевом из 2016. год. - прва два су усаглашена, што је и очекивано, јер је М. Дешић један од чланова правописне комисије која је радила на Матичином правопису, док су решења у Симићевом правопису наглашено слободна, па су често могући и дублети.

7. Неусклађеност између приручника и спољни утицаји довели су до различитих решења у пракси. Актуелно стање репрезентовано је примерима из електронских медија.

\section{1. псеудо}

- сложеница

Псеудодокументаристичку форму Рауове представе можемо тумачити и као одраз њеног садржаја, (само)критичности према (псеудо)бризи Европљана за покоље у неевропским земљама (Политика, 30. 9.2016, е-издање).

- $\quad$ полусложеница

Разговетно је изграђена једна псеудо-историјска, дубоко иронична драма (Политика, 15. 2. 2010, е-издање)

- синтагма

Свакодневно смо бомбардовани псеудо истинама (Политика, 19. 9. 2016, е-издање).

\footnotetext{
${ }^{7}$ Сви анализирани префиксоиди у Хрватском правопису (Бабић/Могуш 2011) први су део сложеница.
} 


\section{2. квази (иста агенцијска вест)}

- сложеница

Квазидржава Косово главни извор регионалне нестабилности (Данас, 3. 5. 2017, е-издање)

\section{- $\quad$ полусложеница}

Русија о Харадинају: Квази-држава је извор проблема (Наслов, Б92, 3. 5. 2017, е-издање).

\section{- синтагма}

Ово показује да је квази држава Косово главни извор регионалне нестабилности (Блиц, 3. 5. 2017, е-издање).

\section{3. контра}

- сложеница

Турски контраадмирал затражио азил у САД (Политика, 10. 8. 2016, е-издање).

- полусложеница

Турски контра-адмирал наводно затражио азил у САД (Ало, 10. 6. 2016, е-издање).

- синтагма

Контра адмирал Валериј Куликов требало [би] да преузме оперативну команду (В. новости, 4. 9. 2013, е-издање).

8. Стање у писаној пракси може се повезати и са утицајима страних језика, пре свега енглеског. Тако није страно да се префиксоиди пишу у оригиналној графији ${ }^{8}$ :

Сви су се ех-напредњаци /.../ преселили у нашу кафану (Пекић 1990: 319). Ех-радикали се баве њима (Данас, 7. 4. 2016, е-издање).

9. Други пример представља реч „post-truth”, коју су састављачи Оксфордског речника изабрали за реч 2016. године, а ту вест пренели наши медији преводећи је као „пост-истину” (Блиц, 16. 11. 2016, е-издање).

10. Процес стандардизације ометају случајеви осамостаљивања префиксоида - налазимо их у прилошком и придевском значењу, што правописни речници бележе, али не доследно, јер је реч о супстандардној лексици (за примере употребе речи/префиксоида супер в. Видојковић 2014). Поред овог примера, у жаргону честа је синонимна употреба префиксоида екстра-, мега-, макси- и ултра- у значењу „изузетно, сјајно” (в. Герзић 2012). Коначно ту је и префиксоид екс- у значењу „бивши, -a, -e”- нпр. Он је Иванин екс (нпр. бивши супруг).

11. Посебан део анализе посвећен је врстама речи. Наиме, међу примерима у правописним речницима највише је именица, што је и очекивано, јер

\footnotetext{
${ }^{8}$ Наведени примери су из латиничних текстова. На основу изостанка ћириличних примера са латиничним префиксоидима можемо с резервом закључити да су они у пракси готово и немогући.
} 
је то и најбројнија врста, а и у грађењу речи, поготово страним формантима, именице су преовлађујућа врста. Међутим, у случајевима са двоструким решењима, попут префиксоида ауто-, неопходно је међу примере уврстити и друге речи којима су именице у ствари творбена основа. Ипак, ниједан приручник од анализираних у правописним речницима не даје управо такве примере, а само у речнику Дешићевог приручника налазимо придев аутосаобраћајни као изведеницу, али без именичког еквивалента (ауто-саобраћај). Ситуација је нешто боља у случају префиксоида фото-, али само донекле, јер само П60 у речнику даје примере попут фӧто-монта́жа: фото-мо̀нтатжнй; фӧто-репо̀рте̄p: фото-репо̀ртерскӣ; фототера̀nија: фототера̀пијскии; фотохѐмија: фотохѐмйјскй. Ни глаголи, као секундарне творенице, нису заступљени у правописним речницима, па тако на пример у П2010 изостаје у пракси веома чест глагол фотокопирати, од којег је изведена опет веома фреквентна глаголска именица фотокопирање.

12. За анализу смо одабрали префиксоид ауто-, заступљен у свим правописним речницима9 9

Табела 3: Префиксоид ауто- у правописним приручнициима

\begin{tabular}{|c|c|c|c|}
\hline \multirow{3}{*}{$\begin{array}{l}\text { Право- } \\
\text { писни } \\
\text { приру- } \\
\text { чници }\end{array}$} & \multicolumn{3}{|c|}{ Префиксоид ауто- } \\
\hline & полусложеница & \multicolumn{2}{|l|}{ сложеница } \\
\hline & $\begin{array}{c}\text { 2) скр. од } \\
\text {,аутомобил” }\end{array}$ & 1) „само” & $\begin{array}{c}\text { 2) скр. од } \\
\text { „аутомобил” }\end{array}$ \\
\hline МП60 & $\begin{array}{l}\text { а̀уто-дрезӥна, } \\
\text { а̀уто-елѐктича̄p, } \\
\text { а̀уто-кӓмера, } \\
\text { а̀уто-клуิб, } \\
\text { а̀уто-ко̀ва̄ч, } \\
\text { а̀уто-кӧла̄p, } \\
\text { а̀уто-коло́на, } \\
\text { а̀уто-лѝма̄p, } \\
\text { а̀уто-меха̀нича̄p, } \\
\text { а̀уто-пуิт, } \\
\text { а̀уто-ста̀јалйште, } \\
\text { а̀уто-стӧп, } \\
\text { а̀уто-стра́да, } \\
\text { а̀уто-тапѐта̄р, } \\
\text { а̀уто-упра̀вља̄ч, } \\
\text { а̀уто-цёста, } \\
\text { а̀уто-шо̀фе̄p }\end{array}$ & $\begin{array}{l}\text { аутобио̀граф, аутобиогра̀фија, } \\
\text { аутобио̀графйјскй, аутобио̀- } \\
\text { графскӣ, ауто̀ге̄н, } \\
\text { аутого̄л, } \\
\text { ауто̀грам, } \\
\text { ауто̀граф, аутогра̀фија, } \\
\text { аутодѝктат, аутодида̀ктичкй, } \\
\text { аутоинду̀кција, ӓутоке̄фалан, } \\
\text { аутокефа́лно̄ст, ауто̀крат(а), } \\
\text { аутокра̀тија, ауто̀кратскй, } \\
\text { аутокрѝтика, аутокрѝти- } \\
\text { ча̄р, аутокритицѝзам, } \\
\text { аутокрѝтичан, аутокрѝтичкй, } \\
\text { аутокрѝтичност, аутома̀ти- } \\
\text { чан, ауто̀матскй, ауто̀номан, } \\
\text { аутономйстичкй, аутоно̀мија, } \\
\text { аутоно̀мист(а), ауто̀скоп, } \\
\text { аутоско̀пија, аутосугѐстија, } \\
\text { аутохипно́за, аутохро̀ман, } \\
\text { ауто̀хто̄н, аутохто́ност }\end{array}$ & $\begin{array}{l}\text { ауто́бус, } \\
\text { ауто̀дром, } \\
\text { а̀утока̄p, } \\
\text { аутопла̀стика }\end{array}$ \\
\hline
\end{tabular}

9 Због малог броја примера, и то свих са значењем „само” (аутограф, аутодидактички, аутономија), Белићев правопис (изд. 1952) није увршћен у табелу. 


\begin{tabular}{|c|c|c|c|c|}
\hline МП93 & \multicolumn{2}{|c|}{$\begin{array}{l}\text { ауто-гума, ауто-купон, ауто- } \\
\text {-камп, ауто-кућа, ауто-опрема, } \\
\text { ауто-пијаца, ауто-трговац, } \\
\text { ауто-превоз, ауто-превозник, } \\
\text { ауто-рели, ауто-салон, ауто- } \\
\text {-такмичење, ауто-мото друшт- } \\
\text { во, ауто-мото клуб, ауто-мото- } \\
\text { трке/ауто и мото трке }\end{array}$} & $\begin{array}{l}\text { аутобиографија, аутокомен- } \\
\text { тар, аутопортрет, аутосуге- } \\
\text { стија, аутократ(а), аутокефа- } \\
\text { лан, -лна }\end{array}$ & $\begin{array}{l}\text { аутодром, } \\
\text { аутопут, ау- } \\
\text { тострада, ау- } \\
\text { тоелектричар, } \\
\text { аутолакирер, } \\
\text { аутолимар, ау- } \\
\text { томеханичар }\end{array}$ \\
\hline & 1) „само” & $\begin{array}{c}\text { 2) скр. од } \\
\text { „,аутомобил” }\end{array}$ & & \\
\hline $\begin{array}{l}\text { Симић и } \\
\text { др. } 1993\end{array}$ & $\begin{array}{l}\text { ауто-био- } \\
\text { граф, ауто- } \\
\text { биографија, } \\
\text { ауто-гол, } \\
\text { ауто-кон- } \\
\text { трола, ауто- } \\
\text { критика }\end{array}$ & $\begin{array}{l}\text { ауто-гаража, } \\
\text { ауто-колона, } \\
\text { ауто-команда, } \\
\text { ауто-лакирер, } \\
\text { ауто-мото, } \\
\text { ауто-промет, } \\
\text { ауто-пут, } \\
\text { ауто-стоперка, } \\
\text { ауто-страда, } \\
\text { ауто-такси, } \\
\text { ауто-трка, } \\
\text { ауто-школа }\end{array}$ & $\begin{array}{l}\text { аутократија, аутоматизација, } \\
\text { аутономија }\end{array}$ & \\
\hline МП2010 & $\begin{array}{l}\text { ауто-електрг } \\
\text { рер, ауто-ли } \\
\text { ауто-гума, ау } \\
\text {-кућа, ауто-с } \\
\text { ауто-цистерґ } \\
\text { ауто-пијаца, } \\
\text { ауто-дилер, } \\
\text { ауто-превозґ } \\
\text { ауто-трансп } \\
\text { ауто-цеста, а } \\
\text {-такмичење, } \\
\text {-спорт, ауто- } \\
\text { ауто-мафија, } \\
\text { и мото трке, } \\
\text { ауто-стоперг }\end{array}$ & $\begin{array}{l}\text { ap, ауто-лаки- } \\
\text { p, ауто-тапетар, } \\
\text { о-купон, ауто- } \\
\text { гон, ауто-парк, } \\
\text { ауто-опрема, } \\
\text { то-трговац, } \\
\text { то-превоз, } \\
\text { к, ауто-такси, } \\
\text { т, ауто-пут, } \\
\text { го-рели, ауто- } \\
\text { уто-трка, ауто- } \\
\text { оп, ауто-стопер, } \\
\text { уто-бомба, ауто } \\
\text { 'то-мото савез, }\end{array}$ & $\begin{array}{l}\text { аутобиографија, аутобио- } \\
\text { графски, аутогол, аутограф, } \\
\text { аутокефалност, аутокоментар, } \\
\text { аутокритичан, аутопилот, } \\
\text { аутопортрет, аутореферат, ау- } \\
\text { тоопсервација, аутосугестија, } \\
\text { аутохипноза, аутоцензура } \\
\text { аутобиограф, аутокефалан, } \\
\text { аутократ(а), аутократија }\end{array}$ & $\begin{array}{c}\text { аутодром, } \\
\text { аутострада }\end{array}$ \\
\hline
\end{tabular}




\begin{tabular}{|c|c|c|c|}
\hline $\begin{array}{l}\text { Дешић } \\
2015\end{array}$ & $\begin{array}{l}\text { а̀уто-гӱма, а̀уто-де́лови, а̀уто- } \\
\text { мӧто тр̈ке/ а̀уто и мӧто тр̈ке, } \\
\text { а̀уто-инду̀стрија, а̀уто- } \\
\text {-лаки́рер, а̀уто-меха̀нича̄p, } \\
\text { а̀уто-пѝјаца, а̀уто-пре́воз- } \\
\text { нйк, а̀уто-пуิт, а̀уто-стӧпер, } \\
\text { а̀уто-тӓблица, а̀уто-тр̈ка, } \\
\text { а̀уто-школла }\end{array}$ & $\begin{array}{l}\text { аутобиогра̀фија, аутобио̀- } \\
\text { графскй, а̀утого̄л, ауто̀грам, } \\
\text { аутономмја, аутономмст(а), } \\
\text { аутопо̀ртре̄т, аутосугѐстија, } \\
\text { аутоцензу́ра }\end{array}$ & $\begin{array}{l}\text { ауто́бус, } \\
\text { ауто́бускй, } \\
\text { ауто̀дром, } \\
\text { ауутостра́да }\end{array}$ \\
\hline $\begin{array}{l}\text { Симић } \\
2016\end{array}$ & $\begin{array}{l}\text { а̀уто-пуิт, ауто-регулатива } \\
\text { (неакцентовано), а̀уто-такси, } \\
\text { а̀уто-трка }\end{array}$ & а̀утогол, ауто̀грам, ауто̀граф & аутостра́да \\
\hline
\end{tabular}

13. Разлика између полусложеница и сложеница успостављена је на основу разлике између значења морфеме ауто- (1. „само”; 2. „скр. од аутомобил”), али недоследно. На пример, у три речника налазимо сложеницу aуmoстра́da (П2010; Дешић 2015; Симић 2016) у којој је примењено правило спојеног писања суфиксоида -страда (као и са суфиксоидом -дром у $а у$ тодром) и која представља позајмљеницу из италијанског језика у значењу „ауто-пут”.

14. Од наведених сложеница и полусложеница, најфреквентнија у пракси је полусложеница ауто-nуm, са првим делом у значењу „скр. од аутомобил”. За ову твореницу везује се и промена стандарда у односу на П93.

Табела 4: Твореница ауто-пут у правописним приручницима

\begin{tabular}{|l|c|c|}
\hline \multirow{2}{*}{ Правописни приручници } & \multicolumn{2}{|c|}{ aуто-nym/aymonym } \\
\cline { 2 - 3 } & полусложеница & сложеница \\
\hline МП60 & а̀уто-пут & \\
\hline МП93 & & аутопут \\
\hline Симић и др. 1993 & ауто-пут & \\
\hline МП2010 & ауто-пут & \\
\hline Дешић 2015 & а̀уто-пут & \\
\hline Симић 2016 & а̀уто-пуิт & \\
\hline
\end{tabular}

15. Иако је у правописним речницима полусложенички начин писања овог појма преовлађујући, промена стандарда у пракси није у потпуности прихваћена ${ }^{10}$ :

Радови на изградњи аутопутева у Србији полако се приводе крају (Блиц, 5. 8. 2017, $11)^{11}$. Аутопут Ниш - Приштина, који се већ назива „аутопут мира”, боље би повезао регион (В. новости, 15. 3. 2017, е-издање). Румунија и Србија су одлучиле да одустану од пројекта повезивања Темишвара и Београда аутопутем (Политика, 22. 5. 2017, е-издање).

${ }^{10}$ Саобраћајни знаци с овом речју посебна су врста примера.

${ }^{11}$ У истом тексту још пет пута само као сложеница. 
16. Актуелно решење дато у П2010 подразумева да се као критеријум узима значење форманта, што је примењиво једино у случају префиксоида ауто- (а) „само”, б) скраћено од „,аутомобил”" и фото- (а) „светлост”, б) скраћено од „фотографија”). За Р. Симића критеријум је акценат. Наиме, „носе ли префиксоиди посебне акценте, а основе посебне (...), ваља их одвајати цртицом” (Симић 2016: 115). Р. Симић овде прави аналогију са решењима примењеним у полусложеницама типа ѝндо-ѐвропски које имају два акцента, те је први део полусложенице још уз то и скраћени облик. Оба критеријума научно су утемељена, што је и основа сваког нормирања. Ипак, често се губило из вида, а то је видљиво и у нашој последњој табели, да се промена норме не сме вршити по сваку цену, те да се олако пређе преко праксе која већ познаје једно нормирано решење. Други проблем јесте да правописни речник актуелног Матичиног правописа не нуди акцентоване одреднице. На извесну недоследност норме врло јасно указује М. Николић управо на примеру двају префиксоида ауто- и фото-, подсећајући да је о томе писао још И. Клајн истичући да у (полу)сложеницама чији је први део ауто- „немамо именицу ауто (у противном бисмо очекивали и да се може рећи *аутомобил-nут и сл.) него префиксоид ауто" (Клајн 1978: 192).

\section{4. Закључак}

1. Иако се нисмо директно бавили питањем терминологије јер се назив за ове творбене елементе у правописним речницима и не помиње, видели смо да је неопходно ускладити називе за префиксе и префиксоиде страног порекла у правописној литератури. Решење префиксоид које нуде М. Дешић и Р. Симић прихватљиво је пре свега као решење које и својим називом упућује корисника правописа да је реч о јединственој лексичкој јединици, чиме се и на тај начин доприноси уједначености норме. Добро решење, поготово у оквиру правописне терминологије, било би и оно које нуди М. Радовић Тешић називајући „све оно што има функцију префикса (а то значи и негацију, префиксоиде и сл. елементе који долазе испред лексичке основе, заправо целе речи)" префиксалним елементима (Радовић Тешић 2009: 109).

2. Коначно, после анализе могуће је одговорити и на питање систематизације решења у вези са писањем префиксоида и сродних страних форманата. У литератури се констатује (Симић и др. 1998: 83; Симић 2016): „процеси од којих зависи правописна систематика управо су у току, и не дозвољавају да тачно одредимо њихову физиономију и статус. (...) У нашем случају може вредети следеће упутство: да се држимо колико је могуће правила о изговору; иначе префиксоиде да пишемо слободно - састављено и са цртицом” (Симић 2016: 115-116). Ово решење кориснике „ослобађа сваке одговорности” јер су могућа барем два решења (када је реч о форманту супер, и три, в. Симић

${ }^{12}$ Овај тип скраћивања није неуобичајен у пракси, нпр. афро-, астро-, гастро-, инфо- и сл. (в. Хорват/Штебих Голуб 2010: 5). 
2016). То ремети и у пракси устаљена решења са доследном нормом (нпр. мега-, контра-, квази-, пост-), јер је неминовна аналогија са решењима која предвиђају слободан (или слободнији) начин писања. Слободнији приступ, односно флексибилнија норма у овом случају није решење и због утицаја стране ортографије (ту мислимо на енглеску). Такође, електронски медији постају све заступљенији, па информације долазе до корисника (читалаца) врло често без лекторских интервенција. Коначно, флексибилност норме која је овде испољена кроз дублетизам често се у пракси манифестује парасистемски у свим правописним правилима, што конкретно значи да се и у погледу осталих правописних правила јавља лажни дублетизам (Зељић 2011).

3. Једно од битнијих питања које смо у раду поставили јесте и избор примера којима илуструјемо неко правописно правило и начин њиховог представљања у правописном речнику. Видели смо да аутори на два начина представљају речи с префиксоидима. Начин који налазимо у Матичиним правописима практичнији је јер се речи групишу око заједничког префиксоида, па је правило о начину писања уочљивије, а самим тим лакше је и уочавање критеријума за нормирање. Добар је и други начин (нпр. у Симић 2016), јер корисник правописног речника налази конкретну реч (сложеницу или полусложеницу), али је успостављање правила и аналогија отежано. Даље, преовладавање именица је очекивано и оправдано, али изостанак секундарних твореница - придева и глагола - ствара дилеме у пракси које управо правописни речници треба да разреше. Дали смо пример са префиксоидима аутои фото- јер је управо ту значењски критеријум био примаран да се направи разлика између сложеница и полусложеница, па је било неопходно истаћи и додатне критеријуме који се користе у нормирању приликом грађења секундарних твореница типа фотокопирати, фотокопирање и сл., што би, у конкретном случају, подразумевало да поред одреднице у загради стоји нпр. „изведеница од...”, „изведено од...” „према...”'13, што би кориснику омогућило да аналогијом успостави системска решења и у другим случајевима. На крају, бројем примера се нисмо бавили, јер смо анализирали приручнике из различитог времена, па су и различити примери били (или јесу) актуелни.

4. Да закључимо, решење које не прави значењску разлику и подразумева добијање сложеница слагањем са страним формантом (префиксоидом) било би, са становишта праксе, најекономичније и не би реметило досадашњи правописни (али и речнички) узус (в. Пешикан 1994). Такође, на тај начин искључили бисмо могуће дилеме, које, очекивано, воде ка стварању паралелних, ненормираних решења, често под утицајем стране графије.

\section{ИЗВОРИ}

Видојковић 2014: Марко Видојковић, Уредник, Београд: Лагуна.

${ }^{13}$ У П93 нпр. краљичин (према краљица), в. П93: 397, исто П2010: 351. 
Пекић 1990: Борислав Пекић, Године које су појели скакавцุи, 3. књига, Београд: БИГЗ - Јединство.

Ало

10. 8. 2016, е-издање

http://www.alo.rs/vesti/svet/turski-admiral-trazi-azil-u-sad/65183/vest, посећено 28. 9. 2017.

\section{Б92}

3. 5. 2017, е-издање

https://www.b92.net/info/vesti/index.php?yyyy=2017\&mm=05\&dd=03\&nav category $=11 \&$ nav_id $=1256537$,

посећено 28. 9. 2017.

\section{Блиц}

16. 11. 2016, е-издање

http://www.blic.rs/kultura/vesti/post-istina-rec-2016-godine-po-oksfordskomrecniku/105lm6h, посећено 6. 9. 2017.

3. 5. 2017, е-издање

http://www.blic.rs/vesti/politika/ostra-poruka-rusije-ministarstvo-spoljnihposlova-osudilo-agresivne-izjave-haradinaja/tw3gbnj, посећено 17. 8. 2017.

5. 8. 2017, 11 (штампано издање)

16. 9. 2017, е-издање

Вечерње новости

15. 3. 2017, е-издање

http://www.novosti.rs/vesti/naslovna/ekonomija/aktuelno.239.html:655118Mihajlovic-Autoput-do-Pristine-za-vecu-stabilnost, посећено 27. 9. 2017.

\section{Данас}

7. 4. 2016, е-издање

http://www.danas.rs/danasrs/politika/djb_.56.html?news_id=318634, посећено 6. 9. 2017.

\section{Политика}

15. 2. 2010, е-издање

http:/www.politika.rs/sr/clanak/123841/Kultura/Rasecanje-nacionalnih-mitova, посећено 16. 3. 2017.

19. 9. 2016, е-издање

http://www.politika.rs/sr/clanak/363804/Sta-se-krije-iza-lazi, посећено 16. 3. 2107.

30. 9. 2016, е-издање

http://www.politika.rs/scc/clanak/364551/Licemerje-zapadnog-sveta, посећено 16.3. 2017. 22. 5. 2017, е-издање

http://www.politika.rs/scc/clanak/381163/Srbija-odustala-od-autoputa-BeogradTemisvar, посећено 22. 9. 2017. 


\section{ЛИТЕРАТУРА}

Бабић/Могуш 2011: S. Babić, M. Moguš, Hrvatski pravopis, Zagreb: Školska knjiga. Белић 1923: А. Белић, Правопис српскохрватског књижевногјезика, Београд: Издавачка књижарница Геце Кона.

Белић 1952: А. Белић, Правопис српскохрватског књижевног језика, Београд: Просвета.

Герзић 2012: Б. Герзић, Речник српског жаргона, Београд: СА.

Дешић 2015: М. Дешић, Правопис српског језика, иколско издање, Београд: Klett.

Зељић 2011: Г. Зељић, Дублетна решења у Правопису српског језика, Иновације у настави, XXVI/2, 64-70.

Јовановић 2008: В. Јовановић, О неким поступцима лексикографске обраде твореница, Наш језик, XXXIX/1-4, 43-52.

Клајн 1978: И. Клајн, О префиксоидима у српскохрватском језику, Наш језик, XXII/5, 187-198.

Клајн 2003: И. Клајн, Творба речи у савременом српском језику, књ. 1 и 2, Београд: Завод за уџбенике и наставна средства.

Ломпар 2012: В. Ломпар, Граматика, уибеник за први разред гимназија и средюих стручних школа, Београд: Klett.

Ломпар 2015: В. Ломпар, Граматика, уибеник за трећи разред гимназија и средњих стручних школа, Београд: Klett.

Михајловић 1985: Ј. Михајловић, Термин видео, Нам језик, XXVI/4-5, 241-252.

Николић 1995-1996: М. Николић, Један експанзивни тип именичких сложеница (Беобанка и сл.), Наш језик, XXX/1-5, 82-95.

Пешикан 1994: М. Пешикан, Поређење понуђених правописних правила, Наш језик, XXIX/5, 259-278.

П93: М. Пешикан, Ј. Јерковић, М. Пижурица, Правопис српскога језика, Нови Сад: Матица српска.

П2010: М. Пешикан, Ј. Јерковић, М. Пижурица, Правопис српскога језика, Нови Сад: Матица српска.

Пипер/Клајн 2013: П. Пипер, И. Клајн, Нормативна граматика српског језика, Нови Сад: Матица српска.

Поповић 1994: М. Поповић, Ка могућој клсификацији страних речи с најучесталијим префиксима грчког и латинског порекла, Наш језик, XXIX/5, 279-300.

П60: Правопис српскохрватскога књижевног језика, Нови Сад, Загреб: Матица српска, Матица хрватска, 1960.

Радовић Тешић 2009: М. Радовић-Тешић, $C$ речима и речником, Београд: Учитељски факултет.

Рогић 1961/62: P. Rogić, Funkcija predmetka u stvaranju novih riječi i značenja, Jezik, IX, 106-111.

Симић и др. 1993: Р. Симић, Ж. Станојчић, Б. Остојић, Б. Ћорић, М. Ковачевић, Правопис српскога језика са речником, Београд, Никшић. 
Симић и др. 1998: Р. Симић (одг. ур.), Правописни приручник српскога книжевног језика, Београд: Научно друштво за неговање и проучавање српског језика.

Симић 2016: Р. Симић, Српски правопис, Београд: Јасен.

Станојчић/Поповић 2008: Ж. Станојчић, Љ. Поповић, Граматика српскога језика, уџбеник за гимназије и средње школе, Београд: Завод за уџбенике.

Стевановић 1991: М. Стевановић, Савремени српскохрватски језик (Граматички системи и књижевнојезичка норма), Београд: Научна књига.

Tафра/Кошутар 2009: B. Tafra, P. Košutar, Rječotvorni modeli u hrvatskom jeziku, Suvremena lingvistika, 67, 87-107.

Хорват/Штебих Голуб 2010: М. Horvaт, В. Štebih Golub, Posljedice internacionalizacije u hrvatskome jeziku, Rasprave Instituta za hrvatski jezik i jezikoslovlje 36/1, 1-21.

hорић 2008: Б. Ћорић, Творба именица у српском језику, Београд: Друштво за српски језик и књижевност Србије.

Шипка 2010: М. Шипка, Правописни речник српског језика са правописно-граматичким саветником, Нови Сад: Прометеј.

Goran N. Zeljić

PREFIXOIDS AND FORMANTS OF FOREIGN ORIGIN IN ORTHOGRAPHIC DICTIONARIES OF THE SERBIAN LANGUAGE

Summary

This paper analyzes prefixoids and formants of foreign origin (mostly Greek and Latin) that are included in orthographic dictionaries of the Serbian language starting with Belić's orthography from 1923, through Matica srpska's editions and Dešić's orthography handbook from 2015, to Simić's orthography handbook from 2016. The aim of the paper is to examine the representation of the words with prefixoids and foreign formants in orthographic dictionaries of the Serbian language and establish the principle of their orthographic standardization.

Key words: orthography, orthographic dictionary, prefixoid, compound, semi-compound. 